\title{
Erratum to: Apoptosis mediated leishmanicidal activity of Azadirachta indica bioactive fractions is accompanied by Th1 immunostimulatory potential and therapeutic cure in vivo
}

\author{
Garima Chouhan ${ }^{1}$, Mohammad Islamuddin', Muzamil Y. Want ${ }^{1}$, Malik Z. Abdin², Hani A. Ozbak ${ }^{3}$, \\ Hassan A. Hemeg ${ }^{3}$, Dinkar Sahal ${ }^{4}$ and Farhat Afrin ${ }^{3^{*}}$
}

\section{Erratum}

Unfortunately, the original version of this article [1] contained an error within the author list. Affiliation 1 was incorrectly assigned to Dr Farhat Afrin. The correct author list and affiliations can be found here. In addition the acknowledgment of the original article is missing supporting information. The correct acknowledgements can be found below.

\footnotetext{
Acknowledgements

This present study was supported by the Deanship of Scientific Research (grant number 7127), Taibah University, Kingdom of Saudi Arabia. This work also received financial assistance from Department of Science and Technology, Department of Biotechnology and Central Council for Research in Unani Medicine (CCRUM), Government of India. G.C. was formerly a recipient of Senior Research Fellowship from CCRUM and is presently a recipient of Basic Science Research Fellowship from University Grants Commission (UGC), under UGC-Special Assistance Grant (SAP) received by Department of Biotechnology, Jamia Hamdard. Our thanks are due to Dr. N. Ali, Indian Institute of Chemical Biology, Kolkata, India, for providing us with L. donovani strain. The authors wish to thank Mr. T. A. Nagarjuna and Dr. V. Gupta, BD-JHFACS Academy, Jamia Hamdard, for their help and cooperation in flow cytometry work. We are thankful to Dr. A. Kumar, Jawaharlal Nehru University, Delhi, India, for his valuable help and guidance in carrying out GC-MS analysis and Dr. A. K. Tiwari for breeding BALB/c mice in Jamia Hamdard Central Animal House Facility. Taibah University, Kingdom of Saudi Arabia is duly acknowledged for meeting the publication cost.
}

\section{Author details}

${ }^{1}$ Department of Biotechnology, Parasite Immunology Laboratory, Faculty of Science, Jamia Hamdard (Hamdard University), New Delhi 110062, India. ${ }^{2}$ Department of Biotechnology, Centre for Transgenic Plant Development, Faculty of Science, Jamia Hamdard (Hamdard University), New Delhi 110062, India. ${ }^{3}$ Department of Medical Laboratories Technology, Faculty of Applied Medical Sciences, Taibah University, P.O. Box: 344, Universities Road, Medina

\footnotetext{
* Correspondence: afrin_farhat@yahoo.co.in

${ }^{3}$ Department of Medical Laboratories Technology, Faculty of Applied Medical Sciences, Taibah University, P.O. Box: 344, Universities Road, Medina 30001, Saudi Arabia

Full list of author information is available at the end of the article
}

30001, Saudi Arabia. ${ }^{4}$ Malaria Research Group, International Centre For Genetic Engineering and Biotechnology, Aruna Asaf Ali Marg, New Delhi 110067, India.

Received: 17 May 2016 Accepted: 17 May 2016

Published online: 27 May 2016

\section{Reference}

1. Chouhan G, Islamuddin M, Want MY, Abdin MZ, Ozbak HA, Hemeg HA, et al. Apoptosis mediated leishmanicidal activity of Azadirachta indica bioactive fractions is accompanied by Th1 immunostimulatory potential and therapeutic cure in vivo. Parasit Vectors. 2015;8:183. doi:10.1186/s13071015-0788-3.

Submit your next manuscript to BioMed Central and we will help you at every step:

- We accept pre-submission inquiries

- Our selector tool helps you to find the most relevant journal

- We provide round the clock customer support

- Convenient online submission

- Thorough peer review

- Inclusion in PubMed and all major indexing services

- Maximum visibility for your research

Submit your manuscript at

www.biomedcentral.com/submit

() Biomed Central 